\title{
ARSITEKTUR MESJID RAYA SULTAN RIAU PENYENGAT SEBAGAI SUMBER BELAJAR MATEMATIKA
}

\author{
Puji Astuti1 ${ }^{*}$, Rifka Mailihastarin ${ }^{2}$ \\ STKIP Insan Madani Airmolek ${ }^{1,2}$ \\ *pujiastuti2695@gmail.com
}

Diterima: 26 April 2021. Disetujui: 28 Juli 2021. Dipublikasikan: 31 Juli 2021

\begin{abstract}
ABSTRAK
Penelitian ini merupakan penelitian kualitatif. Teknik pengumpulan data dilakukan dengan deskriptif. Hasil penelitian menunjukkan bahwa terdapat aktifitas matematika pada Arsitektur Mesjid Raya Sultan Riau Penyengat yaitu aktivitas mengukur, ada beberapa konsep matematika yang terdapat pada arsitektur Mesjid Raya Sultan Riau Penyengat yaitu berupa bangun datar, bangun ruang dan refleksi (pencerminan). Konsep-konsep matematika ini dapat dijadikan sebagai sumber belajar matematika.
\end{abstract}

Kata kunci:Sumber Belajar Matematika, Refleksi.

\begin{abstract}
This research is qualitative. The technique of collecting is the descriptive method. The results show that there are mathematical activities in the Architecture of the Grand Mosque of Sultan Riau Penyengat, namely measuring activity, there are several mathematical concepts contained in the Architecture of Mesjid Raya Sultan Riau Penyengat, namely in the form of flat shapes, building space and reflection of this mathematical concept can be used as a source learn math.
\end{abstract}

Keywords: Mathematics Learning Resources, Reflection.

\section{Pendahuluan}

Pendidikan adalah usaha sadar dan terencana untuk mewujudkan suasana belajar dan proses pembelajaran agar peserta didik secara aktif mengembangkan potensi dirinya untuk memiliki kekuatan spiritual keagamaan, pengendalian diri, kepribadian, kecerdasan, akhlak mulia, serta keterampilan yang diperlukan dirinya, masyarakat, bangsa dan Negara (UUSPN pasal 1 ayat 1). Artinya pendidikan mempunyai peranan yang sangat penting bagi kehidupan manusia. Karena dengan adanya pendidikan, maka manusia akan mempunyai pandangan dan arah hidup yang lebih jelas dan terarah. Oleh karena itu pendidikan yang baik adalah pendidikan yang tidak hanya mempersiapkan peserta didik untuk suatu profesi atau jabatan, tetapi bagaimana pendidikan dapat mempersiapkan peserta didik untuk dapat menyelesaikan masalah yang akan dihadapinya dalam kehidupan sehari-hari dan mampu menerapkannya dalam kondisi apapun.

Dalam Undang-Undang Pendidikan No. 20 Tahun 2003 (Depdiknas, 2003) dijelaskan bahwa fungsi pendidikan nasional adalah untuk mengembangkan kemampuan dan membentuk watak serta peradaban bangsa yang bermartabat dalam rangka mencerdasakan kehidupan bangsa, bertujuan untuk berkembangnya potensi peserta didik agar menjadi manusia yang beriman dan bertaqwa kepada Tuhan Yang Maha Esa, berakhlak mulia, sehat berilmu, cakap, kreatif, mandiri dan menjadi warga Negara yang demokratis serta bertanggung jawab. Salah satu lembaga atau jenjang pendidikan formal yang bertanggungjawab untuk mewujudkan fungsi pendidikan adalah jenjang pendidikan dasar (SD/MI), jenjang pendidikan menengah (SMP/MTS), jenjang pendidikan atas (SMA/MA) dan Perguruan Tinggi.

Pendidikan tidak terlepas dari proses pembelajaran. Banyak cara yang dilakukan guna tercapai tujuan pendidikan. Salah satu diantaranya ialah dengan belajar melalui bangunan-bangunan yang ada disekitar kehidupan sehari-hari. Diantara bangunan tersebut adalah bangunan atau tempat ibadah. Mesjid Raya Sultan Riau Penyengat merupakan salah satu tempat ibadah umat muslim yang terletak di Pulau Penyengat Provinsi Kepulauan Riau. Mesjid ini merupakan salah satu cagar budaya yang sangat terkenal dan menjadi tujuan wisata yang selalu ramai dikunjungi. Mesjid Raya Sultan Riau Penyengat ini tidak 


\section{Range: Jurnal Pendidikan Matematika Vol.3 No.1 Tahun 2021 Puji Astuti,dkk}

hanya sebagai tempat ibadah saja tetapi juga sebagai tempat wisata karena keindahan arsitekturnya serta nilai sejarah yang dapat dijadikan sebagai sumber belajar dan pendidikan. Nilai sejarah serta seni keindahan arsitektur dari Mesjid Raya Sultan Riau Penyengat ini merupakan daya Tarik utama bagi para wisatawan untuk berkunjung. Banyak aktivitas yang dapat dilakukan di Mesjid Raya Sultan Riau Penyengat, ada yang melakukan penelitian untuk mencari informasi tentang nilai sejarah, ada juga yang menjadikan mesjid ini sebagai objek penelitian bahkan ada yang menjadikan masjid ini sebagai sumber belajar terutama belajar matematika.

Salah satu mata pelajaran yang membekali siswa mengembangkan kemampuan-kemampuan tersebut adalah matematika. Menurut (James et al., 1976), matematika diartikan sebagai ilmu logika mengenai bentuk susunan dan konsep-konsep yang saling berhubungan satu sama lainnya dengan jumlah yang terbagi kedalam tiga bidang yaitu aljabar, analisis dan geometri. Sejalan dengan itu (Irwan, 2011) menyatakan bahwa matematika memiliki struktur dan keterkaitan yang kuat dan jelas antar konsepnya sehingga memungkinkan siswa terampil berpikir rasional. Pendidikan matematika mempunyai potensi besar dalam mempersiapkan sumber daya manusia yang berkualitas untuk menghadapi era globalisasi. Potensi ini bisa terwujud jika pendidikan matematika mampu menjadikan siswa yang cakap dalam memahami bahasa simbol dan keteraturan dalam matematika. Matematika menurut (Ruseffendi, 1991) matematika adalah bahasa simbol, ilmu deduktif, ilmu keteraturan, dan struktur yang terorganisasi, mulai dari unsur yang tidak didefinisikan, keunsur yang didefinisikan, keaksioma atau postulat dan akhirnya dalil.

Kemampuan koneksi matematika akan sangat dibutuhkan oleh siswa, terutama untuk memecahkan masalah yang membutuhkan keterkaitan antara konsep matematika dengan konsep lain dalam matematika dan disiplin ilmu atau dalam kehidupan sehari-hari. Perbedaan semacam ini ada bahkan dicabang matematika paling khas seperti halnya perhitungan, pengaturan, klasifikasi, pengukuran dan penimbangan.

Konsep matematika yang dipelajari siswa dalam pembelajaran langsung atau studi lapangan lebih menarik dalam belajar matematika. Mata pelajaran matematika itu bisa menjadi pelajaran yang digemari oleh anak jika dikemas dalam bentuk yang menarik serta dapat dijangkau dengan pemahaman mereka dengan menggunakan konteks seperti masjid atau lingkungan mereka. Proses pembelajaran harus memberikan manfaat bagi siswa agar dapat mengembangkan kemampuannya secara penuh. Matematika dan sains merupakan komponen vital untuk meningkatkan masyarakat kritis dan kemampuan penalaran (Phonapichat et al., 2014)

Pelajaran matematika masih menjadi salah satu pelajaran yang dianggap sulit dan jarang digemari oleh anak atau peserta didik pada umumnya. Karena pelajaran yang diajarkan di sekolah selalu berfokus pada materi yang bersifat kaku dan memaksa anak atau peserta didik untuk berfikir abstrak. Berdasarkan data yang dilansir oleh pusat penilaian pendidikan badan penelitian dan pengembangan Kementerian Pendidikan dan Kebudayaan (Faisal \& Nurgiyatna, 2016), nilai mata pelajaran matematika selalu menjadi nilai mata pelajaran paling rendah diantara mata pelajaran yang diujikan pada Ujian Nasional (UN), hal ini menandakan bahwa pelajaran matematika masih belum jadi mata pelajaran yang digemari peserta didik. (Pernyataan ini tidak memiliki keterkaitan dengan pernyataan-pernyataan sebelumnya)

Berdasarkan uraian di atas, maka penulis melakukan penelitian tentang Eksplorasi Pada Arisitektur Masjid Raya Sultan Riau Penyengat Sebagai Sumber Belajar Matematika.

\section{Metode Penelitian}

Metode penelitian yang digunakan pada penelitian ini yaitu penelitian kualitatif. Menurut (Creswell \& Clark, 2007) penelitian kualitatif merupakan metode untuk mengeksplorasi dan memahami makna sejumlah individu atau sekelompok orang dianggap berasal dari masalah sosial atau kemanusian. Teknik pengumpulan data menggunakan metode deskriptif.

\section{Hasil Penelitian dan Pembahasan}




\section{Range: Jurnal Pendidikan Matematika Vol.3 No.1 Tahun 2021 Puji Astuti,dkk}

Mesjid Raya Sultan Riau Penyengat terletak di kota Tanjung Pinang Provinsi Kepulauan Riau. Mesjid dengan ketebalan dinding mencapai $50 \mathrm{~cm}$ ini merupakan satu-satunya peninggalan Kerajaan Riau-Lingga yang masih utuh. Bahkan, hingga kini masjid ini masih digunakan oleh warga untuk beribadah. Luas keseluruhan kompleks masjid ini sekitar 54,4 m x 32,2 m. Bangunan induknya 29,3 m x 19,5 m dan ditopang oleh empat tiang. Lantai bangunannya tersusun dari batu bata yang terbuat dari tanah liat. Dihalaman masjid terdapat dua buah rumah contoh yang diperuntukkan bagi musafir dan tempat menyelenggarakan musyawarah. Selain itu, dihalaman masjid juga terdapat dua balai, tempat menaruh makanan ketika ada kenduri dan untuk berbuka puasa ketika bulan Ramadhan tiba.

Dari dermaga Panjang dan Pelabuhan Sri Bintan Pura Kota Tajung Pinang, Bangunan measjid Raya Sultan Riau yang berwarna kuning cerah terlihat mencolok diantara bangunan-bangunan lainnya di Pulau Penyengat, pulau kecil seluas 240 hektar. Tiga belas kubah dan empat menara masjid berujung runcing setinggi $18,9 \mathrm{~m}$ yang dulu digunakan oleh muadzin untuk mengumandangkan panggilan shalat membuat bangunan itu tampak megah seperti istana-istana raja di India. Susunan kubahnya bervariasi mengelompok dengan jumlah tiga dan empat kubah. Ketika kubah dan menara tersebut dijumlahkan, akan menunjukkan pada angka 17. Hal ini dapat diartikan sebagai jumlah rakaat dalam shalat yang harus dilakukan oleh setiap umat islam dalam sehari.Sejak dibangun tahun 1832 dengan bangunan beton seperti yang kita lihat sekarang ini. Masjid Sultan Riau Penyengat tidak pernah direnovasi atau diubah bentuknya.

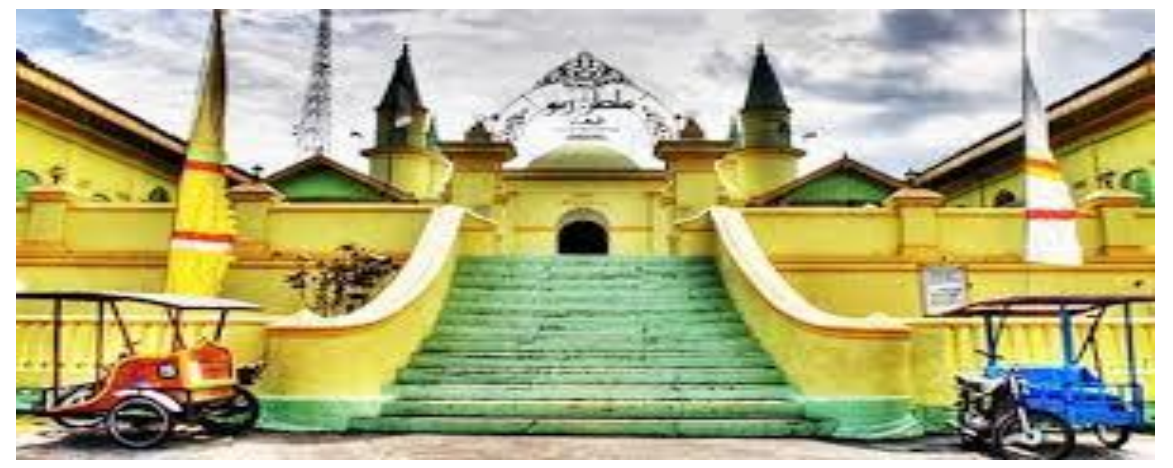

Gambar 1. Mesjid Raya Sultan Riau Penyengat

Berdasarkan Gambar 1 di atas terlihat kemegahan dari Mesjid Raya Sultan Riau Penyengat. Jika dilihat lebih dalam lagi maka akan tampak adanya aktivitas matematika pada arsitektur Mesjid Raya Sultan Riau Penyengat yaitu aktivitas mengukur. Mengukur adalah kegiatan untuk mengetahui perbandingan letak dengan menggunakan satuan ukur pada objek yang hendak diukur sebagai acuan. Aktivitas mengukur sering kali dikaitkan dalam matematika, pada arsitektur Mesjid Raya Sultan Riau Penyengat ini hampir semua bagian bangunan masjid menggunakan aktivitas mengukur. Seperti panjang bangunan, jarak dinding atau ruangan dan sebagainya. Aktivitas mengukur ini terlihat jelas pada bentuk ukuran kubah mesjid, bagian menara dan bagian atas tiang peyangga yang membentuk setengah lingkaran.

Pembangunan setiap mesjid sangat identik dengan kubahnya, begitupun dengan Masjid Raya Sultan Riau Penyengat. Pada pembangunan kubah Mesjid Raya Sultan Riau Penyengat terdapat aktivitas mengukur. Aktivitas mengukur pada bagian kubah ini jelas adanya guna memastikan adanya kesamaan antara satu kubah dengan kubah yang lain. Jumlah kubah yang ada pada Mesjid Raya Sultan Riau Penyengat berjumlah tiga belas buah. Dari ketiga belas buah tersebut, terdapat pengelompokkan bentuk dan ukuran pada kubah tersebut. Pertama, terdapat sepuluh buah kubah yang memiliki bentuk yang sama. Bentuk kubah tersebut menyerupai lima segi tujuh yang melengkung dengan ukuran sisi alas setiap seginya $150 \mathrm{~cm}$. Untuk bentuk kubah Mesjid Raya Sultan Riau Penyengat dapat dilihat pada Gambar 2 berikut. 

Puji Astuti,dkk

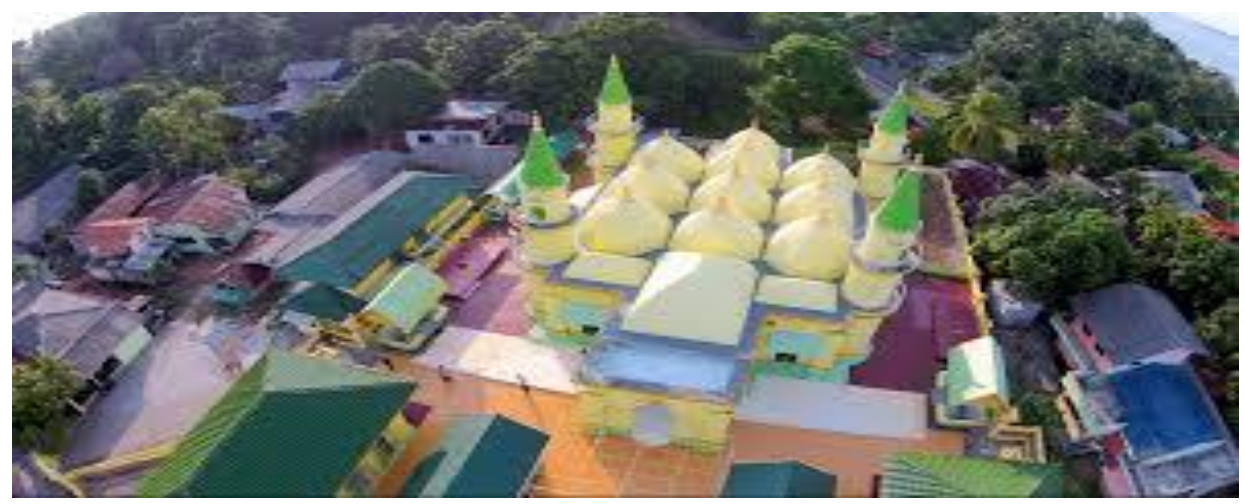

Gambar 2. Kubah Mesjid Raya SultanRiau Penyengat

Dari Gambar di atas terlihat bentuk kubah dari Mesjid Raya Sultan Riau Penyengat. Kemudian kubah berikutnya dengan jumlah dua buah kubah yang sama, yang memiliki ukuran dan bentuk yang juga sama. Bentuk dua buah kubah tersebut menyerupai persegi panjang melengkung. Ukuran sisi alas panjangnya $120 \mathrm{~cm}$ dan lebarnya $80 \mathrm{~cm}$. sedangkan kubah terakhir memiliki ukuran yang lebih besar dari kubah yang lain. Kubah dengan bentuk segi empat melengkung ke atas ini memiliki ukuran sisi alas dengan panjang $220 \mathrm{~cm}$ dan lebar $120 \mathrm{~cm}$.

Selain kubah, aktivitas mengukur pada arsitektur Mesjid Raya Sultan Riau Penyengat ini juga terdapat pada pembuatan bentuk 4 pilar menara di bagian empat penjuru masjid tersebut. Ukuran dan bentuk antara dua menara bagian penjuru depan sama, begitu juga dengan dua pilar menara bagian penjuru belakang. Dua menara bagian depan memiliki bentuk berupa tabung yang memiliki ukuran yang sama antara satu dengan yang lainnya. Sendangkan dua menara bagian belakang lebih kepada bangun segi delapan yang memiliki volume dengan ukuran setiap segi dan keseluruhannya sama. Bentuk bangun ruang lain yang terdapat pada bentuk menara bisa diamati yaitu prisma dan kerucut. Konsep prisma terdapat pada dua menara bagian belakang. Sedangkan konsep kerucut terdapat pada ujung ke empat pilar menara. Berikut Gambar 3 menara Mesjid Raya Sultan Riau Penyengat.

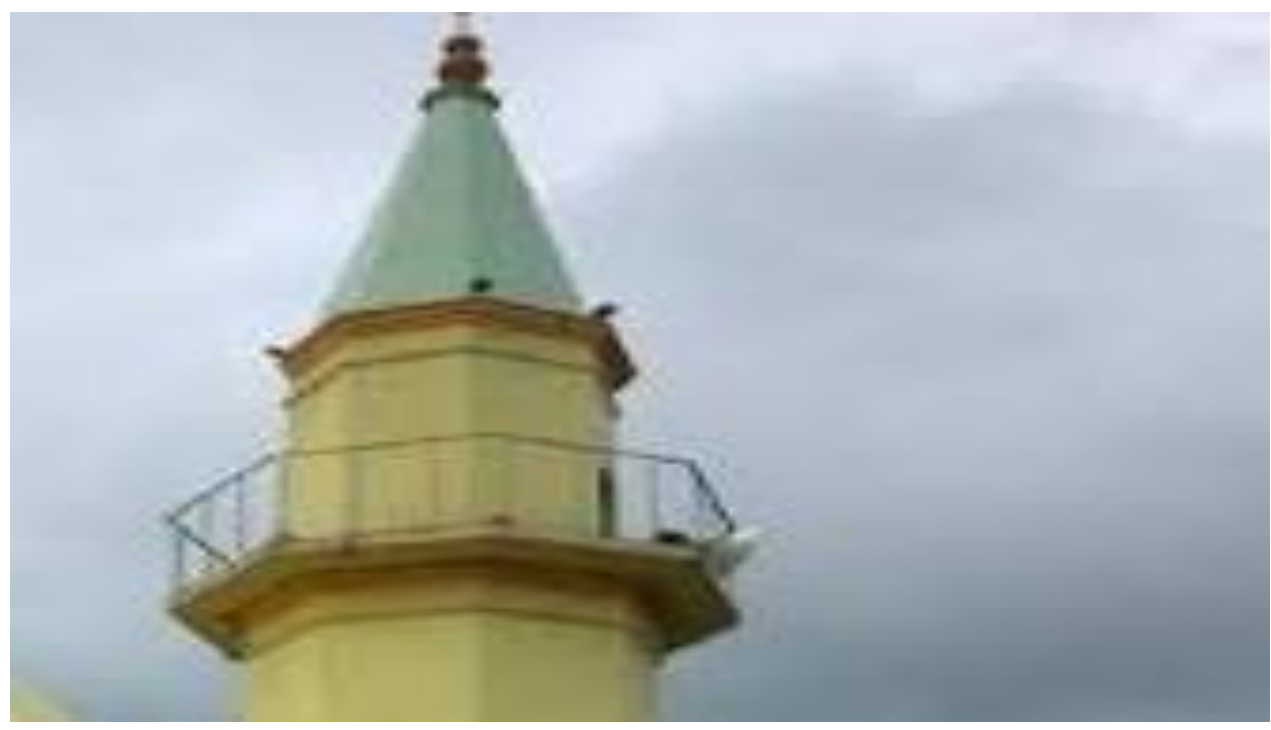

Gambar 3. Menara Masjid Raya Sultan Riau Penyengat

Selanjutnya aktivitas mengukur pada arsitektur Mesjid Raya Sultan Riau Penyengat ini terdapat pada pembuatan tiang penyangga bagian atas masjid tersebut. Bentuk bagian atas dari tiang penyangga tersebut dapat dibilang setengah lingkaran. Ukuran dari lengkungan setengah lingkaran tersebut harus diperhatikan untuk mendapatkan hasil yang bagus dan indah. Hal ini membuat bagian tersebut sesuai dengan konsep dari lingkaran, arsitek harus tahu betul berapa ukuran besar diameter dan jari-jari yang 


\section{Range: Jurnal Pendidikan Matematika Vol.3 No.1 Tahun 2021 Puji Astuti,dkk}

ditetapkan dalam pembuatan bagian ini. Diameter atau jari-jari pada bagian ini mengikuti letak tiang peyangga tersebut. Berdasarkan informasi dari observasi dan wawancara, setiap lengkungan lingkaran yang terdapat pada bagian dalam Masjid Raya Sultan Penyengat ini sama. Diameter pada bagian ini \pm 6 meter dengan panjang jari-jari \pm 3 meter.

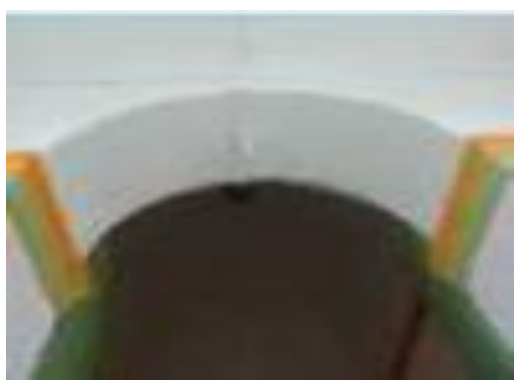

Gambar 4. Tiang Penyangga Bagian Atas

Berdasarkan gambar di atas terlihat bahwa tiang penyangga Masjid Raya Sultan Penyengat berbentuk setengah Lingkaran dengan warna putih dan terdapat warna-warna yang menjadi ciri khas melayu yaitu warna kuning dan hijau.

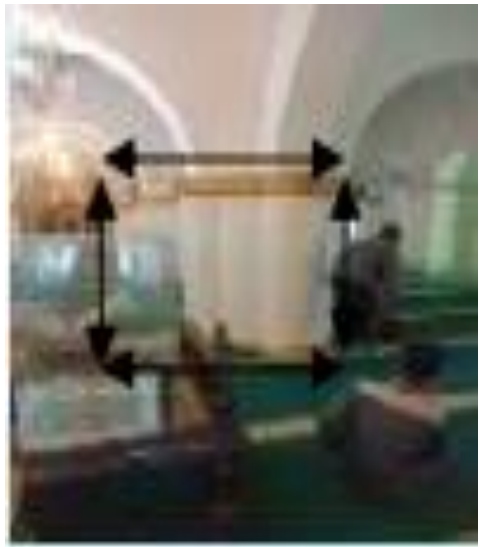

Gambar 5. Tiang peyangga bagian dalam

Pada bagian pintu, terdapat tujuh buah pintu untuk masuk ke bagian dalam Mesjid Raya Sultan Riau Penyengat ini. Pintu-pintu tersebut berada pada bagian depan, kanan dan kiri Masjid Raya Sultan Penyengat. Pada saat observasi ke masjid terlihat bentuk pintu menyerupai tali busur lingkaran.

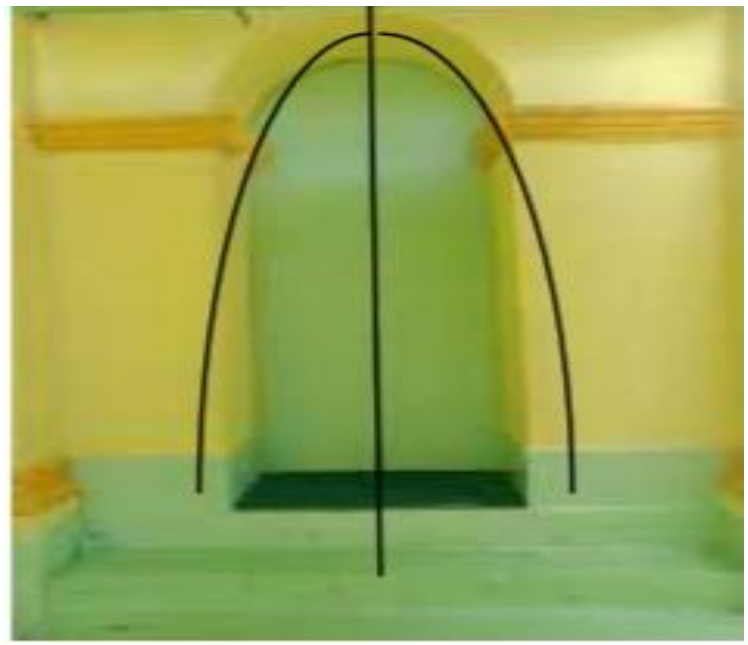

Gambar 6. Pintu Mesjid Raya Sultan Riau Penyengat 


\section{Range: Jurnal Pendidikan Matematika Vol.3 No.1 Tahun 2021 Puji Astuti,dkk}

Selanjutnya aktivitas mengukuryang terdapat pada arsitektur Mesjid Raya Sultan Riau Penyengat ini terdapat pada bagian jendela atau tingkap masjid. Jumlah jendela yang ada pada masjid tersebut berjumlah enam buah. Jendela yang dibuat dengan jumlah tersebut melambangkan atau memiliki filosofi tersendiri yaitu enam buah jendela tersebut mewakili rukun iman umat muslim. Ukuran jendela dari setiap buahnya adalah sama. Berikut bentuk jendela Masjid Raya Sultan Riau Penyengat.

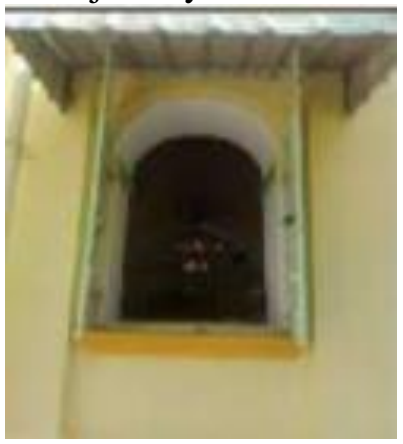

Gambar 7. Jendela Mesjid Raya Sultan Riau Penyengat

Setelah mengetahui bangun apa saja yang ada pada Mesjid Raya Sultan Riau Penyengat yang merupakan aktivitas mengukur, berikut konsep matematika yang ada pada arsitektur Mesjid Raya Sultan Riau Penyengat. Pertama konsep bangun datar. Bangun datar yang dimaksud berupa persegi panjang dan lingkaran yang terdapat pada pintu bagian atas saat dilakukan penarikkan garis pada foto atau gambar pintu bagian atas pintu berbentuk setengah lingkatan.
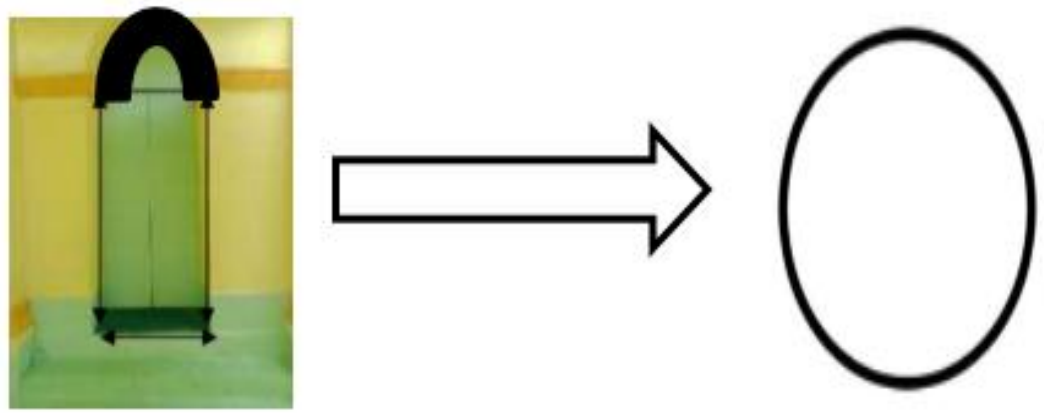

Gambar 8. Pintu Mesjid Raya Sultan Riau Penyengat

Berdasarkan Gambar 8 di atas, jika kita membandingkan pintu masjid dengan konsep matematika maka akan dijumpai bentuk lingkaran. Bentuk ini dapat ditarik dari gambar pintu yang disebelah kiri kemudian dikaitkan dengan konsep matematika maka akan berbentuk bangun datar lingkaran lingkaran seperti gambar yang ada disebelah kanan. Selanjutnya bentuk dari daun pintunya sendiri merupkan persegi panjang. Ini dapat dilihat dari gambar di bawah ini.

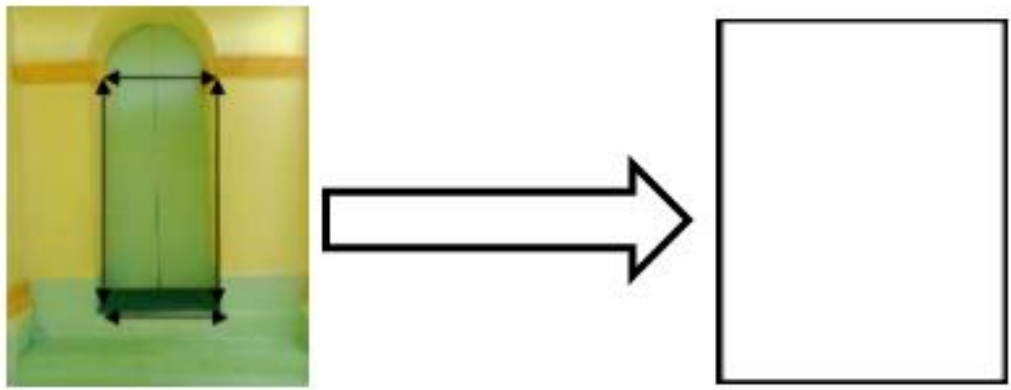

Gambar 9. Daun Pintu Mesjid Raya Sultan Riau Penyengat

Pada arsitektur bagian daun pintu terdapat konsep bangun datar yaitu persegi panjang. Menurut definisi persegi panjang adalah bangundatar segi empat yang keempat sudutnya siku-siku dan sisi-sisinya berhadapan sama panjang. 


\section{Range: Jurnal Pendidikan Matematika Vol.3 No.1 Tahun 2021 Puji Astuti,dkk}

Konsep matematika yang kedua adalah konsep bangun ruang yang berupa balok, limas melengkung segi tujuh dan segi empat serta tabung yang terdapat pada bagian dinding, kubah dan pilar menara yang ada pada Mesjid Raya Sultan Riau Penyengat.
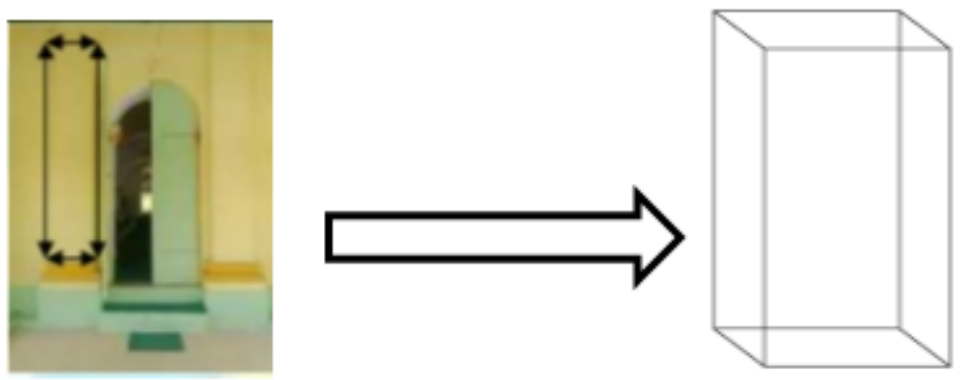

Gambar 10. Dinding Mesjid Raya Sultan Riau Penyengat

Konsep balok terlihat jelas pada bagian arsitektur dinding yang bervolume. Bagian tersebut dapatdikatakan balok karena jika diukur panjang dan lebarnya akan diketahui luas dan volumenya. Selanjutnya puncak menara masjid yang berbentuk limas. Dapat dilihat pada Gambar 11 berikut ini.
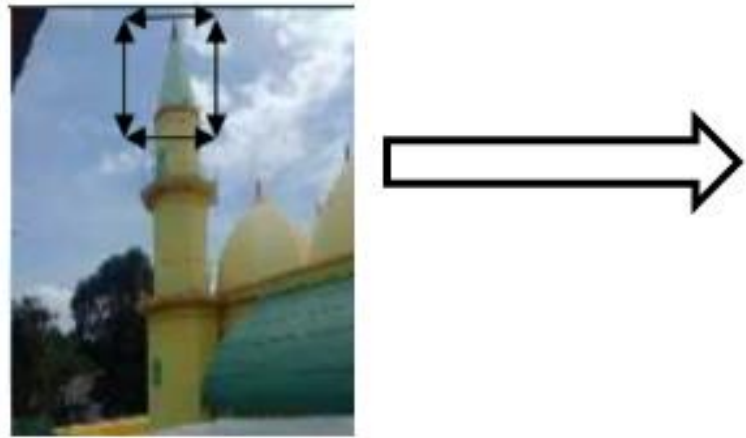

Gambar 11. Puncak Menara Mesjid Raya Sultan Riau Penyengat

Dari Gambar 11 diketahui dari hasil pengamatan bahwa bentuk puncak menara masjid merupakan berbentuk limas segi tujuh. Hal ini diketahui pada saat eksplorasi terhadap menara yang terdapat pada ujung menara. Definisi limas segi tujuh merupakan limas yang memiliki alas berisi tujuh.
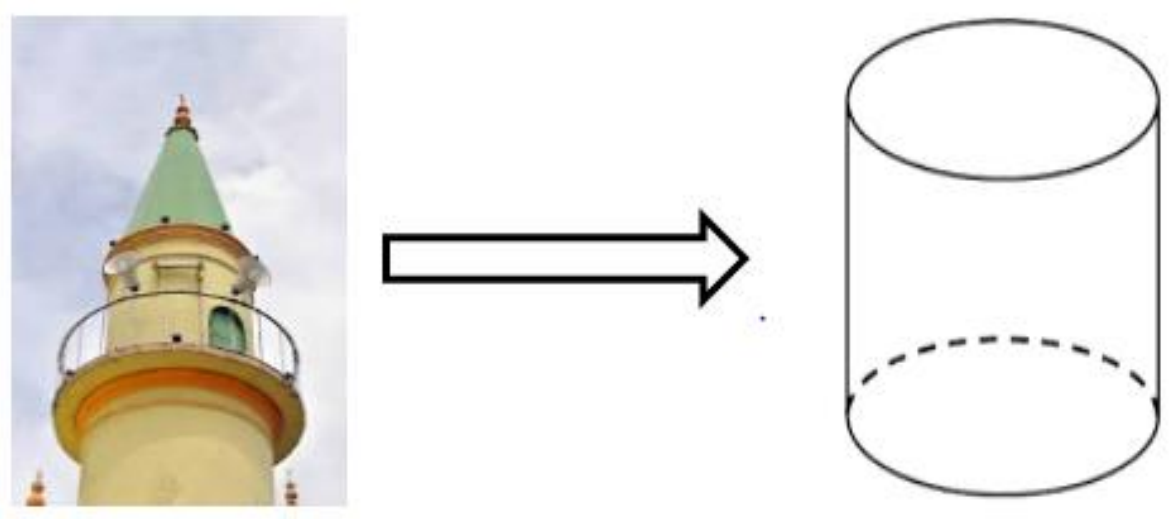

Gambar 12. Menara Mesjid raya Sultan Riau Penyengat

Konsep tabung terlihat jelas pada bagian arsitektur bentuk menara yang ada di Mesjid. Bagian ini bisa dikatakan berbentuk tabung. Bila diameter menara diketahui, maka jari-jari, keliling alas tabung dapat dihitung. Artinya tinggi menara Mesjid dapat dihitung.

Aktivitas geometri terakhir yang terdapat Mesjid Raya Sultan Riau Penyengat adalah transformasi geometri yang merupakan refleksi (pencerminan). Sifat ini dapat dilihat pada bentuk pintu dan jendela kiri dan kanan Mesjid. Bentuk pintu Mesjid Raya Sultan Riau Penyengat dapat dilihat pada Gambar berikut. 

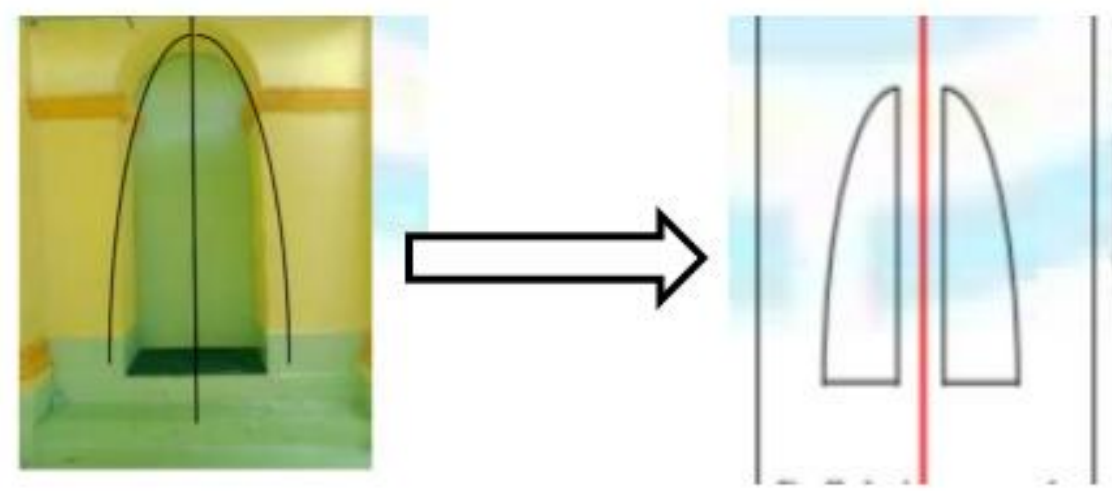

Gambar 13. Daun Pintu Mesjid Raya Sultan Riau Penyengat

Selanjutnya bentuk daun pintu Mesjid Raya Sultan Riau Penyengat memiliki konsep refleksi (pencerminan). Dikatakan refleksi karena bentuk pintu kiri dan kanannya memiliki bentuk dan ukuran yang sama. Jika gambar sebelah kiri yang merupakan bentuk asli dari daun pintu masjid di buat sketsanya maka akan terlihat bentuk pencerminan dari daun pintu tersebut. Selain daun pintu pada masjid yang menggunakan transforomasi geometri daun jendela masjid juga menggunakan transformasi geometri berupa refleksi (pencerminan). Berikut gambar daun jendela Mesjid Raya Sultan Riau Penyengat.
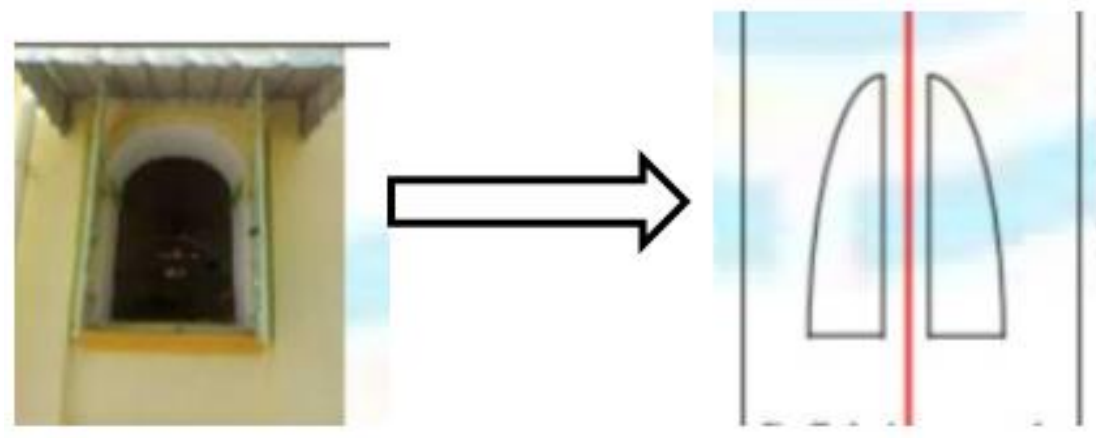

Gambar 14. Daun Jendela Mesjid Raya Sultan Riau Penyengat

Bentuk daun jendela Mesjid Raya Sultan Riau Penyengat memiliki konsep refleksi (pencerminan). Dikatakan refleksi karena bentuk daun jendela kiri dan kananya memiliki bentuk dan ukuran yang sama. Bentuk daun jendela bagian atas berbentuk tali busur lingkaran. Bila ditarik garis cermin horisontal ditengah jendela, maka akan terlihat konsep refleksi seperti gambar 14 sebelah kanan.

\section{Kesimpulan}

Ada beberapa konsep matematika yang ada pada arsitektur Mesjid Raya Sultan Riau Penyengat, yang pertama yaitu bangun datar berupa persegi panjang dan lingkaran yang terdapat pada bagian pintu. Saat dilakukan penarikan garis serta bagian atas pintu aan membentuk setengah lingkaran, yang kedua bangun ruang berupa balok, limas melengkung segi tujuh dan segi empat, serta tabung yang terdapat pada bagian dinding, kubah dan pilar menara yang ada pada masjid Raya Sultan Riau Penyengat. Ketiga adalah transformasi geometri yang terdapat pada arsitektur Mesjid Raya Sultan Riau Penyengat yaitu refleksi (pencerminan) terdapat pada bentuk pintu dan jendela kiri dan kanan yang sama. Banyak sekali konsep matematika yang terdapat pada Mesjid Raya Sultan Riau Penyenga yang dapat dijadikan sebagai sumber belajar matematika bagi siswa. 


\section{Range: Jurnal Pendidikan Matematika Vol.3 No.1 Tahun 2021 Puji Astuti,dkk}

\section{Daftar Pustaka}

Creswell, J. W., \& Clark, V. L. P. (2007). Designing and Conducting Mixed Methods Research. Sage Punlication, Inc.

Depdiknas. (2003). Undang-Undang RI No.20 tahun 2003 tentang sistem pendidikan nasional.

Faisal, A. N., \& Nurgiyatna. (2016). Sistem Informasi Geografis Web untuk Peyebaran Fasilitas Umum di Kabupaten Klaten. In Jurnal Program Studi Teknik Informatika. Universitas Muhammadiyah Surakarta.

Irwan. (2011). Pengaruh Pendekatan Prolem Posing Model Search, Solve, Create and Share (SSCS) dalam Upaya Meningkatkan Kemampuan Penalaran Matematis Mahasiswa Matematika. Jurnal Penelitian Pendidikan, 12(1), 1-13.

James, G., James, R. C., \& Alchian, A. A. (1976). Mathematic Dictionary (Fourth Edi). Van Nostrand Reinhold.

Phonapichat, P., Wongwanich, S., \& Sujiva, S. (2014). An Analysis of Elementary School Students' Difficulties in Mathematical Problem Solving. Procedia - Social and Behavioral Sciences, 116, 3169-3174. https://doi.org/10.1016/j.sbspro.2014.01.728

Ruseffendi, E. T. (1991). Penilaian Pendidikan dan Hasil Belajar Siswa Khususnya dalanı Pengajaran Matematika untuk Guru dan Calon Guru. Tarsito. 